\title{
CDS SPREADS DETERMINANTS OF CONTRACTS INCLUDED IN MARKIT ITRAXX EUROPE SENIOR FINANCIALS INDEX
}

\author{
[Determinanty CDS spreadů kontraktů zahrnutých v indexu Markit iTraxx \\ Europe Senior Financials]
}

\author{
Veronika Kajurová ${ }^{1}$ \\ ${ }^{1}$ Masaryk University, Faculty of Economics and Administration, Lipová 41a, 60200 Brno \\ Email:vkajurova@mail.muni.cz
}

\begin{abstract}
Credit default swap spreads can be used as an indicator of the potential situation in a firm or economy. The instruments for credit risk management become popular among investors and together with a boom of financial innovation, a credit default swap index contract was introduced in June 2004. Since credit default swap spreads represent an indicator of credit risk, the investors and other market participants are interested in factors that can affect credit default swap spread. The aim of this paper is to examine the influence of selected determinants of contracts included in iTraxx Europe Senior Financials index on credit default swap spreads using monthly changes. To capture the changing role of the selected determinants, a panel regression is employed in the crisis and the postcrisis periods. The results confirm the findings of previous research and show that the theoretical relationships hold in cases when observed determinants are statistically significant. Furthermore we proved that the determinants are dependent on the prevailing market circumstances.
\end{abstract}

Keywords: CDS index, credit default swap, determinant, iTraxx, panel regression, spread.

JEL classification: C23, C58, G01, G15, G20

Doručeno redakci: 24.2.2015; Recenzováno: 12.3.2015; 7.4.2015; Schváleno k publikování: 27.5.2015

\section{Introduction}

Focusing on credit default swap (CDS) markets development, one can notice that they have experienced growing number of contracts except of period when the financial crisis hit. The growing number of contracts proves that CDS contracts are popular instruments among financial market participants which primarily allow them to manage credit risk. Except of standard single-name CDS contracts, special products were developed in order to manage credit risk, but their characteristics differentiate a bit from standard contracts.

In June 2004, Markit iTraxx CDS index was introduced. In comparison with standard CDS single-name contract, a contract on a CDS index provides credit protection on the pool of names in the index and they do not terminate when a credit event occurs to a CDS index member or if the first reference entity in the pool defaults. These contracts are much more liquid compared to single-name or basket CDS contacts, which brings another advantages to the owner of a contract. Furthermore, these instruments can be used for other purposes in addition to the credit risk management. Their prices can be used by prudential authorities to extract warning signals regarding financial stability (Annaert et al., 2013). The use of index that covers especially financial institutions seems to be very useful from the point of view of prudential authorities. Therefore we focused our attention to the Markit iTraxx Europe Senior Financial index that includes 25 equally weighted CDSs on investment grade European entities.

The aim of this paper is to examine the influence of selected determinants of contracts included in iTraxx Europe Senior Financials index on CDS spreads using monthly changes. We believe that panel data regression will bring the interesting insight into the determinants 
influence compared to studies that used OLS regression or Markov switching model. Moreover, our dataset covers the post crisis period till January 2015 and hence fills the gap in research since it tries to find out if theoretical relationships between changes in selected variables and changes in CDS spreads hold and if these relationships changed after the crisis.

The results can be useful for all financial market participants trading credit risk, for the prudential authorities and for researchers as well. Since CDS spreads provide and reflect information about financial health of a company or economy, it seems to be very important to identify the drivers of CDS contracts and to investigate what role these drivers have in CDS price discovery process.

The rest of the paper is organized as follows: The literature is reviewed in Section 1. The used methodology is described in Section 2; dataset is introduced and described in Section 3. Section 4 summarizes the gained results and the last section concludes the paper.

\section{Literature review}

Since the CDS index contracts are relatively new contracts in the financial markets, the literature on determinants of spreads is limited. A large number of published studies concerns the determinants of spreads of single-name CDS contracts. The authors deal with the influence of firm-specific factors and market factors on CDS spreads or with the relationships between individual markets (stock, bond and CDS markets). Before the outbreak of the financial crisis, one can find only a few studies devoted to the CDS spreads determinants, e. $\mathrm{g}$. Hull et al. (2004), Norden and Weber (2004 and 2009), Zhu (2004), Blanco et al. (2005), Abid and Naifar (2006a and 2006b), Dötz (2007) or Fabozzi et al. (2007).

Together with the crisis outburst, the interest of many researchers, investors and other financial market participants focused on the determinants of CDS prices since during the crisis period many these contracts came to default and caused high losses. The authors try to investigate especially the relationship between theoretical determinants and CDS prices, inspired by the Merton structural model (see Merton, 1974), e. g. Ericsson et al. (2009), Forte and Peña (2009), Cesare and Guazzarotti (2010), Tang and Yan (2010), Annaert et al. (2013), Coro et al. (2013), Coudert and Gex (2013), Galil et al. (2014), Mayordomo et al. (2014) or Narayan et al. (2014).

Apart from studies that are devoted to the CDS spreads determinants of single name CDS contracts, several studies concerning CDS indices have also been published. The first study dealing with the CDS indices is the study written by Byström (2005). It is focused on the link between the CDS market and the stock market. Using correlations, rank correlations and OLS regressions, he found out that stock returns explain much of the variability in CDS spreads; therefore firm-specific information is reflected into stock prices before it is reflected into CDS spreads. Another interesting conclusion is that stock index volatility is found to be significantly correlated with CDS index spreads. Even though the results are interesting, the main disadvantage of research is that the dataset covers only the period from June 2004 to April 2005 (daily closing quotes).

Alexander and Kaeck (2008) employed a Markov switching model of the determinant of changes in CDS indices with conclusion that they are extremely sensitive to stock volatility during periods of CDS market turbulence and that CDS spreads are much more sensitive to stock returns during ordinary market circumstances. They used daily quotes during the period from June 2004 to June 2007. 
Naifar (2011a) studies the nonlinear relationship between stock market conditions and the default risk premium for the Australian market. The dependence structure among the CDS, stock index level and jump risk using Archimedean copulas is modelled. The results are supportive of the extreme co-movement of CDS and equity market conditions. Another paper by Naifar (2011b) deals with the relationship between default risk premium, stock market conditions and macroeconomic variables during the financial crisis in Japan. Employing Markov switching model, the results showed that during the crisis period, CDS indices behave as a higher-risk indicator and become more sensitive to stock market conditions and macroeconomic variables. Naifar (2012) also examined the dependence structure between default risk premium, equity volatility and the jump risks using five different copulas and iTrax CDS index data from Japanese and Australian markets. It proves that the study of dependence structure between default risk premium and equity market conditions is aligned with the regulatory objective of improving financial stability.

The latest paper by Avino and Nneji (2014) investigates the forecasting performance for CDS spreads of both linear and non-linear models using daily quotes of iTraxx Europe CDS indices for the period from September 2005 to September 2010. They found that linear models often outperform Markov switching models, but the findings raise some doubts on the efficiency of the European CDS index market.

\section{Methodology}

We use panel estimation techniques for evaluation of the relationships between changes in selected variables and consequent changes in spreads of CDS contracts included in iTraxx Europe Senior Financials index. We decided to employ panel regressions like e. g. Tang and Yan (2010), Annaert et al. (2013) or Coro et al. (2013), since OLS regression and Markov switching model used mainly in previous studies were based on data summation for each variable (e. g. stock return was calculated as a sum of stock prices of all companies included in the index), therefore the results could be a bit distorted. Moreover, according to Hsiao (2003) panel data sets for economic research possess several major advantages over conventional cross-sectional or time-series data sets. Panel data give the researcher a large number of data points, increasing the degrees of freedom and reducing the collinearity among explanatory variables.

Panel regressions are employed separately in the crisis period and the post crisis period in order to find out whether the influence of selected variables has changed in different economic circumstances. We decided to use the model with changes, since variables are in different units and using levels could lead to biased results. The changes are calculated to the previous period. The choice of determinants included in the model is inspired by previous published studies, but is limited by data availability. The detailed characteristics on used variables are provided in the following section Data (see Table 2). The model is specified as follows:

$$
\begin{aligned}
& \quad \Delta C D S_{i t}=\alpha_{i}+\beta_{1} \Delta C D S_{i(t-1)}+\beta_{2} \Delta C V O L_{i t}+\beta_{3} \Delta L I Q_{i t}+\beta_{4} \Delta L E V_{i t}+\beta_{5} \Delta E V O L_{i t}+ \\
& \quad+\beta_{6} \Delta M V O L_{j t}+\beta_{7} \Delta M R E T_{j t}+\beta_{8} \Delta E F I N R E T_{j t}+\beta_{9} \Delta E F I N V O L_{j t}+\beta_{10} \Delta O I S_{j t}+ \\
& +\beta_{11} \Delta S T S_{j t}+u_{i t}
\end{aligned}
$$

where $i$ identifies reference entity specific explanatory variables, $j$ identifies common market explanatory variables, $t$ is time period, $C D S$ is CDS spread and $\triangle C D S_{i t}=C D S_{i t}-C D S_{i(t-1)}$, $C D S_{i(t-1)}$ is lagged CDS spread, $C V O L$ is CDS spread volatility, $E V O L$ is equity historical volatility, $L I Q$ is bid-ask spread, $L E V$ is leverage (equity return), $M V O L$ is market volatility, 
MRET is market index return, EFINRET represents financial sector return, EFINVOL denotes volatility of financial sector return, OIS is risk-free rate, STS is slope of term structure and $u$ is error term.

Prior to panel regression, a Hausman test (Hausman, 1978) had been employed in order to find out which estimation should be used - fixed or random effect estimation (Andreß et al., 2013). The results of tests (unreported here) showed that the fixed effect estimation should be employed.

\section{Data}

The iTraxx Europe Senior Financials index includes 25 the most liquid single-name CDSs in the European markets. The index is equally weighted and is rolled every six month (in March, 20 and September, 20). The latest series available in Bloomberg database is a series seven, therefore the sample period starts in September 2007. All data are obtained from Bloomberg database on monthly frequency. We used the index, in which CDSs of 5-year maturity are listed. 5-year maturity was chosen in accordance with Mayordomo's et al. (2013) contribution which shows that this maturity-provider combination reflects new information more rapidly than CDSs of other maturities. The following table provides an overview of 28 financial institutions that are or were listed in the Markit iTraxx Europe Senior Financial index during the observed period. Two institutions are from Netherlands, five from Germany, five from Italy, six from Great Britain, four from France and four from Switzerland.

Table 1: Markit iTraxx Europe Senior Financial index's members and country of origin

\begin{tabular}{|l|c|}
\hline Financial institution & Country \\
\hline Aegon NV & NL \\
\hline Allianz SE & DE \\
\hline Assicurazioni Generali SpA & IT \\
\hline Aviva PLC & GB \\
\hline AXA SA & FR \\
\hline Banca Monte dei Paschi di Siena SpA & IT \\
\hline Banco Bilbao Vizcaya Argentaria SA & ES \\
\hline Banco Popolare SC & IT \\
\hline Banco Santander SA & ES \\
\hline Barclays Bank PLC & GB \\
\hline BNP Paribas SA & FR \\
\hline Commerzbank AG & DE \\
\hline Credit Agricole SA & FR \\
\hline Credit Suisse Group AG & CH \\
\hline Deutsche Bank AG & DE \\
\hline Hannover Rueck SE & DE \\
\hline HSBC Bank PLC & GB \\
\hline ING Bank NV & NL \\
\hline Intesa Sanpaolo SpA & IT \\
\hline Lloyds Bank PLC & GB \\
\hline Muenchener Rueckversicherungs-Gesellschaft AG in Muenchen & DE \\
\hline Royal Bank of Scotland PLC/The & GB \\
\hline Societe Generale SA & FR \\
\hline Standard Chartered Bank & GB \\
\hline Swiss Reinsurance Co Ltd & CH \\
\hline UBS AG & CH \\
\hline UniCredit SpA & IT \\
\hline Zurich Insurance Co Ltd & CH \\
\hline SOurce Blorb & \\
\hline
\end{tabular}

Source: Bloomberg database. 
The observed period (September 2007 - January 2015) is divided into two sub-periods according to trends in development of the Markit iTraxx Europe Senior Financial index - the crisis period (September 2007 - December 2009) and the post crisis period (January 2010 January 2015). The start point was set up as a day for which data were available in Bloomberg database. Data are available from series seven that was rolled in September 2007; therefore we did not investigate the influence of selected variables on CDS spreads in the pre-crisis period. The crisis period is understood as a period of the biggest turmoil in financial markets since the banking crisis had started earlier then Lehman Brothers went bankrupt. Then the crisis transformed into a sovereign debt crisis, although it is denoted as the post-crisis period.

Several explanatory variables that are available on the same frequency as CDS index spreads were used in our analysis. The choice of the variables is inspired by other published works. The selected determinants cover both firm specific and market variables. Table 2 provides a summary of selected determinants, indicators and expected/theoretical relationship between change in determinant and CDS spread.

Table 2: Selected determinants, indicators and expected/theoretical relationship between change in determinant and CDS spread

\begin{tabular}{|l|c|l|c|}
\hline Determinant & Abbr. & Indicator & $\begin{array}{c}\text { Expected } \\
\text { relationship }\end{array}$ \\
\hline CDS spread volatility & CVOL & Historical CDS 30-day volatility & + \\
\hline Financial sector return & EFINRET & EURO STOXX Financial Services index & - \\
\hline Financial sector volatility & EFINVOL & 30-day volatility of financial sector return & + \\
\hline Equity volatility & EVOL & Historical equity 30-day volatility & + \\
\hline Leverage & LEV & Equity returns & - \\
\hline Liquidity & LIQ & CDS Bid-Ask spread & + \\
\hline Market return & MRET & Country's stock market index & + \\
\hline Market volatility & MVOL & $\begin{array}{l}\text { 30-day volatility of country's stock market } \\
\text { index }\end{array}$ & + \\
\hline Risk-free rate & OIS & Overnight index swap rate & - \\
\hline Slope of term structure & STS & 10y-2y government bonds & - \\
\hline
\end{tabular}

Source: Author's construction.

\section{Company Specific Factors}

The stock returns are used as a proxy of leverage. This choice is in accordance with Christie (1982), Alexander and Kaeck (2008) or Annaert et al. (2013) and many others. The negative relationship between the change in leverage and the change in CDS spread is expected if stock returns are negative, leverage will increase, leading to higher credit spreads or vice versa.

Volatilities for stock prices and CDS spreads are calculated. 30-day historical volatility is used instead of implied volatility of individual stock options because of lack of data on options. The positive relation between the change in asset volatility and the change in CDS spread is expected since the higher volatility should lead to the higher credit spreads because of the increased probability of default.

Another company specific factor used in our research is liquidity that can be measured and assessed in many different ways. We decided to use bid-ask spread as a measure of liquidity. We expect the positive relation between changes in liquidity and in following changes in CDS spreads. Lower spread shows on the higher liquidity that should result in the lower probability of default. 


\section{Market Factors}

Our model reflects market factors as well since it is likely that the CDS spreads are not affected only by company specific factors and that the market specific or global factors play an important role in price discovery process.

Countries' stock indices are included as a proxy of business climate and their volatility as a measure of market volatility. The DAX index was used for Germany, the IBEX index for Spain, the CAC Index for France, the UKX for the United Kingdom, the SMI index for Switzerland, the FTSEMIB Index for Italy, and finally the AEX Index for Netherlands. The negative relationship is expected between explanatory variables and explaining variable. The lower market returns should lead to the higher CDS spreads since the lower probability of default is expected. Market volatility should have the reverse impact on CDS spreads because of the increasing uncertainty for all market participants.

Also the EURO STOXX Financial Services index is used as a measure of financial sector climate and its volatility is used as well. Same assumptions are valid for the relationship between changes in index return and changes in CDS spreads and between changes in volatility of the index and changes in CDS spreads.

Our model also takes into consideration the influence of the risk-free rate. Following Hull and White (2013), the overnight index swap (OIS) rate is used as a proxy of risk-free rate. They suggest that OIS rates should be used as the risk-free rate when valuing derivatives instead of LIBOR and LIBOR-swap rates. They also argue that the OIS rate is the most appropriate rate for calculating the no-default value of both collateralized and non-collateralized transactions. The negative relationship is expected between changes in the risk-free rate and changes in CDS spread. According to general knowledge, the lower risk-free rates should lead to the increasing credit spreads and vice versa.

The term structure slope is the last determinant which we include in the model. The slope of term structure is calculated as a difference between the 10year and 2year government bonds. The negative relationship is expected between changes in variables as in the case of the riskfree rate since a high slope anticipates improved economic growth. And in addition, the slope carries information about the future interest rate level as well.

\section{Descriptive Statistics}

The following table summarizes descriptive statistics of used variables separately during the crisis period and the post crisis periods. Probabilities for Jarque-Bera test are not reported since they were equalled to zero; therefore normality was rejected in all cases. 
Table 3: Descriptive statistics

\begin{tabular}{|c|c|c|c|c|c|c|c|c|}
\hline \multicolumn{9}{|c|}{ Crisis period } \\
\hline & Mean & Median & Max & Min & Std. Dev. & Skewness & Kurtosis & Jarque-Bera \\
\hline CDS & 7.99 & 4.2 & 153.73 & -64.92 & 31.82 & 0.86 & 4.18 & 110.65 \\
\hline CVOL & 3.60 & -6.78 & 279.24 & -78.11 & 50.26 & 2.72 & 12.83 & 3221.33 \\
\hline EFINRET & -1.69 & -0.90 & 28.76 & -26.29 & 11.23 & 0.23 & 3.71 & 18.54 \\
\hline EFINVOL & 6.8 & -5.70 & 84.90 & -40.59 & 36.82 & 0.90 & 2.65 & 85.26 \\
\hline EVOL & 7.13 & -4.19 & 247.40 & -52.87 & 40.76 & 1.70 & 7.2 & 707.72 \\
\hline LEV & -1.35 & -1.56 & 90.20 & -62.29 & 15.45 & 0.57 & 7.20 & 484.19 \\
\hline LIQ & 9.82 & 0.00 & 2494.61 & -98.25 & 108.12 & 19.94 & 456.80 & 5300466.0 \\
\hline MRET & -0.96 & -0.60 & 20.80 & -19.72 & 6.95 & -0.04 & 3.6 & 0.21 \\
\hline MVOL & 6.29 & -7.30 & 153.26 & -47.52 & 39.99 & 1.44 & 4.58 & 274.79 \\
\hline OIS & 0.93 & -5.49 & 114.70 & -55.41 & 31.04 & 1.27 & 4.29 & 208.59 \\
\hline STS & 5.38 & 2.10 & 729.23 & -1848.0 & 170.12 & -6.43 & 76.59 & 142538.40 \\
\hline \multicolumn{9}{|c|}{ Post crisis period } \\
\hline & Mean & Median & Max & Min & Std. Dev. & Skewness & Kurtosis & Jarque-Bera \\
\hline $\mathrm{CDS}$ & 1.13 & -1.81 & 75.49 & -37.97 & 17.74 & 0.88 & 4.00 & 253.41 \\
\hline CVOL & 4.99 & -0.33 & 209.71 & -62.09 & 34.66 & 1.75 & 8.36 & 2552.92 \\
\hline EFINRET & 0.01 & 0.18 & 14.49 & -17.43 & 7.2 & -0.21 & 2.64 & 19.12 \\
\hline EFINVOL & 3.57 & -3.78 & 142.95 & -43.82 & 29.86 & 1.85 & 8.60 & 2802.98 \\
\hline EVOL & 4.20 & -1.38 & 206.71 & -74.55 & 32.11 & 1.74 & 8.38 & 2549.61 \\
\hline LEV & 0.18 & 0.51 & 40.38 & -32.75 & 9.12 & 0.07 & 3.96 & 58.90 \\
\hline LIQ & 6.82 & 0.00 & 508.76 & -74.03 & 40.47 & 2.78 & 23.92 & 29165.27 \\
\hline MRET & 0.43 & 0.71 & 16.63 & -19.19 & 4.66 & -0.43 & 4.25 & 144.04 \\
\hline MVOL & 5.22 & -3.52 & 174.38 & -47.80 & 35.42 & 1.77 & 6.89 & 1724.15 \\
\hline OIS & 5.63 & -1.62 & 1000.00 & -112.50 & 63.22 & 11.16 & 168.61 & 1738202.00 \\
\hline STS & 6.11 & -1.83 & 2162.50 & -91.99 & 125.88 & 16.84 & 288.63 & 5149253.00 \\
\hline
\end{tabular}

Source: Author's calculation in Eviews.

\section{Results and discussion}

Firstly, panel regression is employed in the crisis period. The results are reported in Table 4. The explained variation of the model is $28.4 \%$ (adjusted $\mathrm{R}^{2}$ ). The changes in lagged CDS spread, equity volatility, market return, slope of term structure and in financial sector return are statistically significant. Durbin-Watson statistic is 2.17 which shows that the residues are not correlated. The changes in market factors (MRET and EFINVOL) have much bigger impact on changes in CDS spread then the changes in the company specific factors.

When assessing the expected relationship between variables for statistically significant results, our theoretical expectations about sings can be confirmed. Positive (negative) changes in equity volatility and in volatility of financial sector return lead to positive (negative) changes in CDS spreads because the probability of default is increasing (decreasing) during volatile (calm) periods. 
Table 4: Panel regression results - the crisis period

\begin{tabular}{|l|c|c|c|}
\hline Variable & Coefficient & Std. Error & Prob. \\
\hline C & 4.608 & 1.181 & 0.000 \\
\hline CDS(-1) & $\mathbf{- 0 . 1 2 1}$ & 0.038 & $\mathbf{0 . 0 0 2} * *$ \\
\hline CVOL & 0.014 & 0.026 & 0.585 \\
\hline LIQ & 0.016 & 0.010 & 0.131 \\
\hline LEV & 0.025 & 0.112 & 0.823 \\
\hline EVOL & $\mathbf{0 . 1 3 0}$ & 0.045 & $\mathbf{0 . 0 0 4} * *$ \\
\hline MRET & $\mathbf{- 2 . 1 1 6}$ & 0.406 & $\mathbf{0 . 0 0 0} * *$ \\
\hline MVOL & -0.021 & 0.056 & 0.700 \\
\hline OIS & -0.050 & 0.044 & 0.259 \\
\hline STS & $\mathbf{- 0 . 0 2 6}$ & 0.007 & $\mathbf{0 . 0 0 0} * *$ \\
\hline EFINRET & 0.379 & 0.267 & 0.156 \\
\hline EFINVOL & $\mathbf{0 . 1 7 7}$ & 0.062 & $\mathbf{0 . 0 0 4} * *$ \\
\hline $\mathrm{R}^{2}$ & 0.325 & Prob(F-stat $)$ & 0.000 \\
\hline Adj. $\mathrm{R}^{2}$ & 0.284 & DW stat & 2.172 \\
\hline
\end{tabular}

Note: ** denote statistically significant coefficients at $5 \%$ level.

Source: Author's calculation in Eviews.

Positive (negative) changes in market return are followed by negative (positive) changes in spreads since the lower (higher) probability of default is expected. Changes in slope of term structure are also statistically significant. Positive (negative) changes in slope lead to negative (positive) changes in CDS spreads since improved economic growth (economic decline) is anticipated. Lagged changes in CDS spreads are statistically significant as well which can point out to CDS market inefficiency.

Table 5 provides a summary of results in the post crisis period. Explained variation of model increases to $53.6 \%$ in the post crisis period compared to the explained variation in the crisis period. The lower variation of model in the crisis period can be assigned to the existence of other significant variables that should be identified or to another underlying process within price discovery. The changes in lagged CDS spreads, CDS spread volatility, liquidity, leverage, market return, stock market volatility, financial sector return and its volatility are statistically significant in this period and are in accordance with the theoretical assumptions. Compared to the crisis results, changes in equity volatility and slope of term structure were not statistically significant. Durbin-Watson statistic indicates that the residues are not correlated.

Table 5: Panel regression results - the post crisis period

\begin{tabular}{|l|c|c|c|}
\hline Variable & Coefficient & Std. Error & Prob. \\
\hline C & 0.905 & 0.333 & 0.007 \\
\hline CDS(-1) & $\mathbf{- 0 . 1 3 7}$ & 0.019 & $\mathbf{0 . 0 0 0 * *}$ \\
\hline CVOL & $\mathbf{0 . 0 6 1}$ & 0.011 & $\mathbf{0 . 0 0 0} * *$ \\
\hline LIQ & $\mathbf{0 . 0 2 8}$ & 0.008 & $\mathbf{0 . 0 0 1} * *$ \\
\hline LEV & $\mathbf{- 0 . 2 4 6}$ & 0.054 & $\mathbf{0 . 0 0 0}^{* *}$ \\
\hline EVOL & 0.016 & 0.014 & 0.237 \\
\hline MRET & $\mathbf{- 0 . 4 3 1}$ & 0.115 & $\mathbf{0 . 0 0 0}^{* *}$ \\
\hline MVOL & $\mathbf{0 . 0 2 6}$ & 0.015 & $\mathbf{0 . 0 7 8}^{*}$ \\
\hline OIS & -0.005 & 0.005 & 0.333 \\
\hline STS & -0.002 & 0.003 & 0.390 \\
\hline EFINRET & $\mathbf{- 1 . 0 5 2}$ & 0.083 & $\mathbf{0 . 0 0 0} * *$ \\
\hline EFINVOL & $\mathbf{0 . 0 7 3}$ & 0.018 & $\mathbf{0 . 0 0 0} * *$ \\
\hline R $^{2}$ & 0.548 & Prob(F-stat $)$ & 0.000 \\
\hline Adj. R $^{2}$ & 0.536 & DW stat & 2.170 \\
\hline
\end{tabular}

Note: ** denote statistically significant coefficients at $5 \%$ level and * at $10 \%$ level.

Source: Author's calculation in Eviews. 
Positive (negative) changes in volatility variables (CDS spread volatility, stock market volatility and volatility of financial sector return) are followed by positive (negative) changes in CDS spreads since the probability of default is increasing (decreasing). Positive (negative) changes in stock market return and in financial sector return are followed by negative (positive) changes in spreads since the lower (higher) probability of default is anticipated. Changes in firm specific factors seem to have more significant impact on changes in CDS spreads in comparison to the crisis period results. Positive (negative) changes in liquidity lead to positive (negative) changes in CDS prices because of the increasing (decreasing) probability of default. Positive (negative) changes in leverage are followed by a negative (positive) change in CDS spreads due to decreasing (increasing) probability of default. As in in the crisis period, lagged changes in CDS spreads are statistically significant that can be related to CDS market inefficiency.

Even though the panel regression and monthly observations were used, our main results confirm the results of previous works that were focused on determinants of CDS indices spreads, but were employed on a limited data sample not covering the post crisis period. Our research fills this gap since it covers the post crisis period till January 2015. It confirms the previous findings by Alexander and Kaeck (2008) that during the crisis period CDS spreads are much more sensitive to stock market volatility and to changes in stock returns (our variable leverage) during ordinary market circumstances. Also the results of Naifar (2011b) that CDS indices behave as high-risk indicator during the crisis period and become more sensitive to stock market conditions and macroeconomic variables are confirmed. As the latest study by Avino and Nneji (2014) show, our results point out to the possible market inefficiency of CDS index market with focus on financial sector.

\section{Conclusions}

The aim of our paper was to examine the influence of selected determinants of contracts included in iTraxx Europe Senior Financials index on CDS spreads on monthly changes using panel regression. The results confirm the findings of previous studies on determinants of CDS indices and show that the theoretical relationships hold in cases when determinants are statistically significant.

By dividing whole sample period into the crisis period and the post crisis periods, we found out that the determinants are dependent on the prevailing market circumstances. The market factors were much more significant during the crisis period compared to the company-specific factors which could be connected to the global turmoil and fear in the financial markets. During the post crisis period, the market factors still played the important role. Even though we denote the period as the post crisis period, it is the period of the sovereign debt crisis in Europe, therefore the influence of the market factors is not negligible. However, the company-specific factors became more significant during this period compared to the previous period, especially the changes in stock prices. That can point out the change in the pricing of CDS spread and the fact that the market participant started to take into their consideration that the stock value is associated with the company's default and that all information on company's health are included in the stock price.

We also verified that theoretical expectations hold in current circumstances. Moreover, the explained variation of used model was much higher compared to the crisis period. The results can be useful for all financial market participants trading credit risk, for the prudential authorities and for researchers as well. However, the used model did not explain all variation 
of CDS spreads and refers to market inefficiency, thus there still exists a space for future research.

\section{Acknowledgement}

Support of Masaryk University within the project MUNI/A/1127/2014 "Analýza, tvorba a testování modelů oceňování finančních, zajišt’ovacích a investičních aktiv a jejich využití $\mathrm{k}$ predikci vzniku finančních krizí" is gratefully acknowledged.

\section{Literature}

[1] ABID, F. and N. NAIFAR, 2006a. Credit-default swap rates and equity volatility: a nonlinear relationship. The Journal of Risk Finance, 7(4), 348-371. ISSN 1526-5943.

[2] ABID, F. and N. NAIFAR, 2006b. The determinants of credit default swap rates: an explanatory study. International Journal of Theoretical and Applied Finance, 9(1), 2342. ISSN 0219-0249.

[3] ALEXANDER, C. and A. KAECK, 2008. Regime dependent determinants of credit default swap spreads. Journal of Banking \& Finance, 32(6), 1008-1021. ISSN 03784266.

[4] ANDREß, H., K. GOLSCH and A. W. SCHMIDT, 2013. Applied panel data analysis for econometric and social surveys. 1st ed. Berlin Heidelberg: Springer-Verlag. ISBN 9783642329135 .

[5] ANNAERT, J., M. DE CEUSTER, P. VAN ROY and C. VESPRO, 2013. What determines Euro area bank CDS spreads? Journal of International Money and Finance, 32, 444-461. ISSN 0261-5606.

[6] AVINO, D. and O. NNEJI, 2014. Are CDS spreads predictable? An analysis of linear and non-linear forecasting models. International Review of Financial Analysis, 34, 262274. ISSN 1057-5219.

[7] BLANCO, R., S. BRENNAN and I. W. MARSH, 2005. An empirical analysis of the dynamic relation between investment-grade bonds and credit default swaps. Journal of Finance, 60(5), 2255-2281. ISSN 1540-6261.

[8] BYSTRÖM, H. N. E., 2005. Credit default swaps and equity prices: the iTraxx CDS index market. Working Papers, 2005(24). Lund University, Department of Economics.

[9] CESARE, A. Di and G. GUAZZAROTTI, 2010. An analysis of the determinants of credit default swap spread changes before and during the subprime financial turmoil. Working paper, No 749. Bank of Italy.

[10] CORÒ, F., A. DUFOUR and S. VAROTTO, 2013. Credit and liquidity components of corporate CDS spreads. Journal of Banking \& Finance, 37(12), 5511-5525. ISSN 03784266 .

[11] COUDERT, V. and M. GEX, 2013. The interactions between the credit default swap and the bond markets in financial turmoil. Review of International Economics, 21(3), 492505. ISSN 1042-4431.

[12] CHRISTIE, A. A., 1982. The stochastic behaviour of common stock variances: Value, leverage and interest rate effects. Journal of Financial Economics, 10(4), 407-432. ISSN 0304-405X. 
[13] DÖTZ, N., 2007. Time-varying contributions by the corporate bond and CDS markets to credit risk price discovery. Discussion Paper Series 2: Banking and Financial Studies, No 08. Frankfurt am Main: Deutsche Bundesbank. ISBN 978-3-86558-310-9.

[14] ERICSSON, J., K. JACOBS and R. OVIEDO, 2009. The determinants of credit default swap premia. Journal of Financial and Quantitative Analysis, 44(1), 109-132. ISSN 0022-1090.

[15] FABOZZI, F. J., X. CHENG and R.-R. CHEN, 2007. Exploring the components of credit risk in credit default swaps. Financial Research Letters, 4(1), 10-18. ISSN 1544-6123.

[16] FORTE, S. and J. I. PEÑA, 2009. Credit spreads: An empirical analysis on the informational content of stock, bonds, and CDS. Journal of Banking \& Finance, 33(11), 2013-2025. ISSN 0378-4266.

[17] GALIL, K., O. M. SHAPIR, D. AMIRAM and U. BEN-ZION, 2014. The determinants of CDS spreads. Journal of Banking \& Finance, 41, 271-282. ISSN 0378-4266.

[18] HAUSMAN, J. A., 1978. Specification tests in econometrics. Econometrica, 46(6), 1251-1271. ISSN 1468-0262.

[19] HSIAO, CH., 2003. Analysis of panel data. 2nd ed. Cambridge: Cambridge University Press. ISBN 9780521522717.

[20] HULL, J., M. PREDESCU and A. WHITE, 2004. The relationship between credit default swap spreads, bond yields, and credit rating announcments. Journal of Banking \& Finance, 28(11), 2789-2811. ISSN 0378-4266.

[21] HULL, J. and A. WHITE, 2013. LIBOR versus OIS: The derivatives discounting dilemma. Journal of Investment Management, 11(3), 14-27. ISSN 1545-9144.

[22] MAYORDOMO, S., J. I. PEÑA and E. S. SCHWARTZ, 2013. Are all credit default swap databases equal? European Financial Management, 20(4), 677-713. ISSN 1468036X.

[23] MAYORDOMO, S., M. RODRIGUEZ-MORENO and J. I. PEÑA, 2014. Liquidity commonalities in the corporate CDS market around the 2007-2012 financial crisis. International Review of Economics and Finance, 31, 171-192. ISSN 1059-0560.

[24] MERTON, R. C., 1974. On the pricing of corporate debt: The risk structure of interest rates. Journal of Finance, 29(2), 449-470. ISSN 0022-1082.

[25] NAIFAR, N., 2011a. What explains default risk premium during the financial crisis? Evidence from Japan. Journal of Economics and Business, 63(5), 412-430. ISSN 01486195.

[26] NAIFAR, N., 2011b. Modelling dependence structure with Archimedean copulas nad applications to the iTraxx CDS index. Journal of Computational and Applied Mathematics, 235(8), 2459-2466. ISSN 0377-0427.

[27] NAIFAR, N., 2012. Modelling the dependence structure between default risk premium, equity return volatility and the jump risk: Evidence from a financial crisis. Economic Modelling, 29(2), 119-131. ISSN 0264-9993.

[28] NARAYAN, P. K., S. S. SHARMA and K. S. THURAISAMY, 2014. An analysis of price discovery from panel data models of CDS and equity returns. Journal of Banking \& Finance, 41, 167-177. ISSN 0378-4266. 
[29] NORDEN, L. and M. WEBER, 2004. Informational efficiency of credit default swap and stock markets: the impact of credit rating announcements. Journal of Banking \& Finance, 28(11), 2813-2843. ISSN 0378-4266.

[30] NORDEN, L. and M. WEBER, 2009. The co-movement of credit default swap, bond and stock markets: an empirical analysis. European Financial Management, 15(3), 529-562. ISSN 1468-036X.

[31] TANG, D. Y. and H. YAN, 2010. Market conditions, default risk and credit spreads. Journal of Banking \& Finance, 34(4), 734-753. ISSN 0378-4266.

[32] ZHU, H. 2006. An empirical comparison of credit spreads between the bond market and the credit default swap market. Journal of Financial Services Research, 29(3), 211-235. ISSN 1573-0735. 